\title{
Methanolysis of Crude Jatropha Oil using Heterogeneous Catalyst from the Seashells and Eggshells as Green Biodiesel
}

\author{
A. N. R. REDDY ${ }^{1}$, A. S. AHMED ${ }^{1 *}$, M. D. ISLAM ${ }^{2}$ AND S. HAMDAN ${ }^{1}$
}

\begin{abstract}
In this work, heterogeneous calcium oxide catalysts gleaned from Polymedosa expansa and eggshell were investigated for the transesterification of crude jatropha oil with methanol, to access their prospective performance in biodiesel production as an alternative green energy resource. The best yield of biodiesel achieved was $96 \%$ in $1 \mathrm{~h}$ for Step 1 using $0.01: 1$ ratio of acid catalyst to oil and 0.6:1 ratio of alcohol to oil ratio, together with $2 \mathrm{~h}$ of Step 2 using 0.02:1 ratio with base catalyst $\mathrm{CaO}$, derived from P. expansa, to oil ratio and 5:1 ratio of alcohol to oil. The properties of jatropha biodiesel were analyzed and found to have calorific value of $35.43 \mathrm{MJ} / \mathrm{kg}$, density value of 895 $\mathrm{kg} / \mathrm{m}^{3}$ and flash point of 167 . The biodiesel was blended with mineral diesel from B0 to B50 for a diesel engine performance test. B20 indicated comparable characteristics with pure mineral diesel, like lowest fuel consumption rate, specific fuel consumption rate, highest brake horsepower and mechanical efficiency.
\end{abstract}

Key words: Biodiesel; jatropha; heterogeneous catalyst; transesterification; alternative green energy resource

Due to increase in the prices of petroleum, gradual depletion of the world's petroleum reserves and impact of environmental pollution caused by combustion of fossil fuel, the search for substantial alternative energy resources such as biodiesel has gained importance (Lippke et al. 2011). As reported in the role of biodiesels beyond 2020 (Cluzel 2013) biodiesel has imperative role in the energy sector. Compared to the conventional petroleum diesel, biodiesel is renewable, non-toxic, non-flammable, have low pollutant emissions and safe for use in all conventional diesel engines which has the same performance and engine durability. Srithar et al. (2014) and many researchers reported biodiesel can be used alone or can be blended with any ratio of mineral diesel to produce biodiesel blend. The blending of biodiesel with petroleum diesel depicts similar characteristics with lower hazardous exhaust emissions compare to the emission of fossil fuel (Koh et al. 2011).

Biodiesel is a green energy resource, compromises mono alkyl ester of long fatty acids derived from biologically produced oils or fats including vegetable oils, animal fats and microalgae oils (Qien et al. 2010). Initially many researchers and some developing countries are using edible oils such as rapeseed, soybean, palm, sunflower, coconut, and linseed oils as feedstock for commercial produce of biodiesel (Demirbas 2009; Gui et al. 2008).

\footnotetext{
${ }^{1}$ Department of Mechanical Engineering, Faculty of Engineering, Universiti Malaysia Sarawak, 94300 Kota Samarahan, Sarawak, Malaysia

${ }^{2}$ Department of Chemistry, Faculty of Science, Universiti Putra Malaysia, 43400 Serdang, Selangor, Malaysia

* Corresponding author (e-mail: aasaleh@feng.unimas.my)
} 
The use of edible oils for biodiesel production is banned in few countries like china since it's not feasible due to limited availability of per capita agriculture land resources. Hence there is a potential demand and promotion for the non-edible oils like crude jatropha oil (CJO) as feed stock in biodiesel produce (Yang et al. 2010; Deng et al. 2010). The current interest is developing a biofuel with international specifications, without affecting the food demand (Mofijur et al. 2012). Jatropha has been chosen as feedstock due to its adaptability in tropical and sub-tropical climates in marginal and non-agriculture areas. Apart from that, the JCL seeds are found to be toxic to human and animals (Leung et al. 2010). Jatropha Curcas Linnaeus (JCL) comes from Euphorbiaceous family. It is a fast growing tree has a life span of about or more than 50 years (Nahar et al. 2011). Jatropha Curcas Linnaeus contains oil in the seed which is $27 \%$ to $40 \%$ of oil.

There are many methods to produce biodiesel from vegetable oils or animal fats like direct use or blending, pyrolysis, microemulsion and transesterification (Meher et al. 2013; Bobade et al. 2013). Among these, the most common method is transesterification of triglycerides using methanol fatty acid methyl esters (FAME). Also, transesterification is discovered to be the most efficient way to reduce the viscosity of vegetable oils to meet the biodiesel standards like EN 14214. In transesterification, triglycerides in vegetable oil will react with alcohol to form a mixture of and fatty acid alkyl esters. (Chung et al. 2008) reported, in transesterification, based on the amount of free fatty acids (FFA), both acidic-catalysts and basic-catalysts can be used. Since $3 \%$ to $40 \%$ FFAs present in acid oils homogeneous catalysts are not recommendable. Marchetti et al. (2007) and Gubitz et al. (1999) reported that the homogeneous catalyst and the FFA will interact to produce soap. This makes the amount of available catalyst for the transesterification reaction to be reduced and also complicates the down streaming separation and the biodiesel purification further, the rate of transesterification reaction by alkaline catalysts is much faster than that by acid catalysts.

The main focus of the present work was to synthesize heterogeneous base catalysts from the sea shells and egg shells for biodiesel produce from CJO. A comprehensive study on the efficiency of biodiesel conversion from CJO to jatropha biodiesel (JB) by using twostep transesterification to optimize the reaction process and found the best yield of biodiesel was carried out. The properties of biodiesel produced were analyzed through Fourier Transform Infrared Spectrometer (FT-IR), bomb calorimeter, density meter, flash point tester and flue gas analyzer. Subsequently a comparative analytical approach on comparable characteristics of biodiesel blends with pure mineral diesel, such as lowest fuel consumption rate, specific fuel consumption rate, highest brake horsepower and mechanical efficiency were analyzed.

\section{MATERIALS AND METHODOLOGY}

\section{Material and Equipment}

The research was conducted in the Faculty of Engineering, Universiti Malaysia Sarawak. Material used for biodiesel production were CJO, methanol $(\mathrm{MeOH})>99 \%$ pure), sulphuric acid $\left(\mathrm{H}_{2} \mathrm{SO}_{4}\right)$ 95\%-97\%, Desterilized water/pipe water, sodium hydroxide, $\mathrm{NaOH}$, potassium hydroxide $(\mathrm{KOH})$, calcium oxide $(\mathrm{CaO})$ from $P$. expansa and eggshell. Equipment used are magnetic stirrer cum heater, orbital shaker, electronic scale and furnace.

\section{Catalyst Preparation}

Polymedosa expansa, whose scientific name Solander 1786 belongs to 23375 Corbiculidae families and locally it is called as Lokan (Bachok et al. 2003). P. expansa has large rounded, thick-shelled bivalve reaching about $110 \mathrm{~mm}$. Exterior has sculpture of distinct concentric growth lines, often developed as 
ridges with strong and wide hinge and in white or with thick olive-brown periostracum colour. Interior colour is white.

P. expansa shells were collected from a local villager's stall. The edible portion attached to the shells and other impurities were removed, they were rinsed thoroughly with tap water followed by double rising with distilled water. The $P$. expansa shells were dried in hot air oven at for $24 \mathrm{~h}$. The P. expansa shells were tested for calcium, one seashell was dissolved in $10 \% \mathrm{HCl}$ to obtain a large amount of effervescence and a colourless solution. If this solution was added to a sodium carbonate and/or sodium sulphate solution a white precipitate could be formed:

$$
\begin{aligned}
& \mathrm{CaCO}_{3}+2 \mathrm{HCl} \rightarrow \mathrm{CaCl}_{2}+\mathrm{H}_{2} \mathrm{O}+\mathrm{CO}_{2} \\
& \mathrm{CaCl}_{2}+\mathrm{Na}_{2} \mathrm{CO}_{3} \rightarrow 2 \mathrm{NaCl}+\mathrm{CaCO}_{3} \downarrow \\
& \mathrm{CaCl}_{2}+\mathrm{Na}_{2} \mathrm{SO}_{4} \rightarrow 2 \mathrm{NaCl}+\mathrm{CaCO}_{3} \downarrow
\end{aligned}
$$

The dried $P$. expansa shells were ground in an agate mortar until they became a form of powder. Mustakimah et al. (2012), Azimah et al. (2012) and Said et al. (2014) reported the calcination of the seashells using standard process. The shell powder was calcinated in an open furnace at $900^{\circ} \mathrm{C}$ for $2 \mathrm{~h}$. At $850{ }^{\circ} \mathrm{C}$, the calcium carbonate of $P$. expansa shell powder decomposed to calcium oxide and carbon dioxide. Calcium oxide is a white crystalline solid with a melting point of $2572^{\circ} \mathrm{C}$.

Eggshells were collected from UNIMAS (Students Pavilion). Buasri et al. (2013) reported on the calcination of eggshells. The raw eggshells were calcined at temperatures between $300^{\circ} \mathrm{C}$ to $900^{\circ} \mathrm{C}$, for 1,3 and $5 \mathrm{~h}$. The proper calcination conditions were: $900^{\circ} \mathrm{C}$ and $1 \mathrm{~h}$, yielding calcium oxide with a purity of $99.06 \% \mathrm{w} / \mathrm{w}$. The calcium carbonate of the rhombohedral form $\left(\mathrm{CaCO}_{3}\right)$ transformed completely into the calcium oxide or lime of the face-centered cubic form $(\mathrm{CaO})$ at $900^{\circ} \mathrm{C}$.

\section{Free Fatty Acids Measurement}

Titration was adopted to determine the FFA content in crude jatropha oil. It is expressed as the amount of $\mathrm{KOH}$ in $\mathrm{mg}$ required to neutralize $1 \mathrm{~g}$ of fatty acid methyl ester. $\mathrm{KOH} 0.1 \mathrm{M}$ was diluted into ethanol (Azhari et al. 2008; Bojan, et al. 2012). The solid $\mathrm{KOH}$ was fully dissolved in the ethanol by constant stirring. A weight of $2 \pm 0.5 \mathrm{~g}$ of jatropha oil and a 50 ml solvent mixture (95\% ethanol + diethyl ether, $1: 1 \mathrm{v} / \mathrm{v})$ were mixed in a conical flask and heated on the heater with magnetic stirrer. Few drops of phenolphthalein were added to the mixture and titrated. The mixture with the $\mathrm{KOH}$ solution was stirred continuously for $10 \mathrm{~s}$ until the colour of the solution turned pink. The process was repeated three times to increase the accuracy. If the FFA was more than $4 \%$, acid pretreatment was required to be carried out to reduce the FFA value in first step.

\section{Transesterification}

Since the FFA value determined was greater than $4 \%$, acid pretreatment is required. Thus, biodiesel conversion by using two-step transesterification is carried out (Ismail et al. 2014).

\section{Pretreatment (Step 1)}

Filtered $25 \mathrm{ml} \mathrm{CJO}$ was heated over $100^{\circ} \mathrm{C}$ to remove the water content. Mixture of sulphuric acid (catalyst) and methanol (alcohol) were prepared according to the catalyst to oil ratio, alcohol to oil ratio by volume and heated to $50^{\circ} \mathrm{C}$. Oil sample was added to the catalyst mixture and heated to $50^{\circ} \mathrm{C}$ to $60^{\circ} \mathrm{C}$ by using magnetic stirrer for $1 \mathrm{~h}$ then it was allowed to settle down for $1 \mathrm{~h}$. Methanol-water fraction was removed. The remaining oil was washed by using de-sterilized water. It was allowed to settle for $30 \mathrm{~min}$ to remove the water at the lower layer using the separation funnel. The pretreated oil was heated to 100 with magnetic stirrer to remove the water content. 
The pretreated oil was for second step based catalyzed transesterification (Bojan et al. 2012).

\section{Transesterification by Base Catalyst (Step 2)}

The optimum condition obtained which has the lowest acid value was selected to proceed with second step transesterification. The pretreated oil was heated to $50^{\circ} \mathrm{C}$ to make it turn into a clearer fluid. A mixture of $\mathrm{CaO}$ from P. expansa (catalyst) and methanol (alcohol) according to the catalyst to oil ratio and alcohol to oil ratio by volume was prepared and heated up to $50^{\circ} \mathrm{C}$. The oil sample and the catalyst mixture were allowed to react using magnetic stirrer for $2 \mathrm{~h}$ at $60^{\circ} \mathrm{C}$. The mixture was shacked for $2 \mathrm{~h}$ using orbital Shaker at room temperature at 250 r.p.m. speed and allowed the mixture to settle for $24 \mathrm{~h}$. The glycerol stocked at lower layer and the methanol-water fractions at the upper layer were separated. The remaining biodiesel was washed by using de-sterilized water and allowed $30 \mathrm{~min}$ for removing the water at the lower layer in the separation funnel. The filtered biodiesel produced was heated to $100^{\circ} \mathrm{C}$ with a magnetic stirrer, to remove the water content in order to get pure biodiesel. The process was repeated with catalyst calcium oxide $(\mathrm{CaO})$ extracted also from eggshells.

\section{Biodiesel Properties Analysis}

The biodiesel produced was tested by using FT-IR analysis, bomb calorimeter, density meter, flash point tester and flue gas analyzer to compare its properties with diesel and CJO. Engine performance test was conducted by using Jatropha Biodiesel blends to determine the optimum ratio.

\section{RESULTS AND DISCUSSION}

\section{Acid Value}

From Table 1, the acid value obtained was 29.466. The acid value obtained is 29.466 . The acid value was too high so it was not suitable to run one-step esterification. Thus, two-step transesterification was conducted where Step 1 acid pretreatment to reduce the high free fatty acid content in the CJO to less than $4 \%$.

\section{Catalyst to Oil Ratio}

Figure 1 shows the different proportion of acid catalyst which is from $1 \%$ to $6 \%$ to oil ratio by volume, $1 \%$ of sulphuric acid had shown the best result which the FFA value of the Jatropha oil sample was reduced to $1 \%$. Thus, it is suitable for alkali catalyzed transesterification to be carried out.

Figure 2 shows the concentration of the catalyst increases, biodiesel yield also increases. However, it reached optimum condition during 2\% (w/w). Further increases in the concentration of catalyst result in lower yield as more soap formation. Among the catalysts used, Calcium oxide $(\mathrm{CaO})$ from $P$. expansa had shown the highest yield which was $96 \%$ with the concentration of catalyst at $2 \%$ to oil ratio $(\mathrm{w} / \mathrm{w})$.

\section{Methanol to Oil Ratio}

After the FFA value was determined and qualified for alkali catalyzed transesterification process, different ratio of alcohol to oil ratio were tested to identify the optimum proportion of methyl ester yield produced. From Figure 3,

Table 1. Acid value analysis.

\begin{tabular}{c|cccc}
\hline Experiment & Weight $(\mathrm{g})$ & Volume $(\mathrm{ml})$ & Molarity $(\mathrm{mol} / \mathrm{l})$ & Acid value \\
\hline 1 & 2.706 & 14 & 0.1 & 29.024 \\
2 & 2.952 & 15.7 & 0.1 & 29.836 \\
3 & 2.773 & 14.6 & 0.1 & 29.537 \\
Average & & & & 29.466 \\
\hline
\end{tabular}




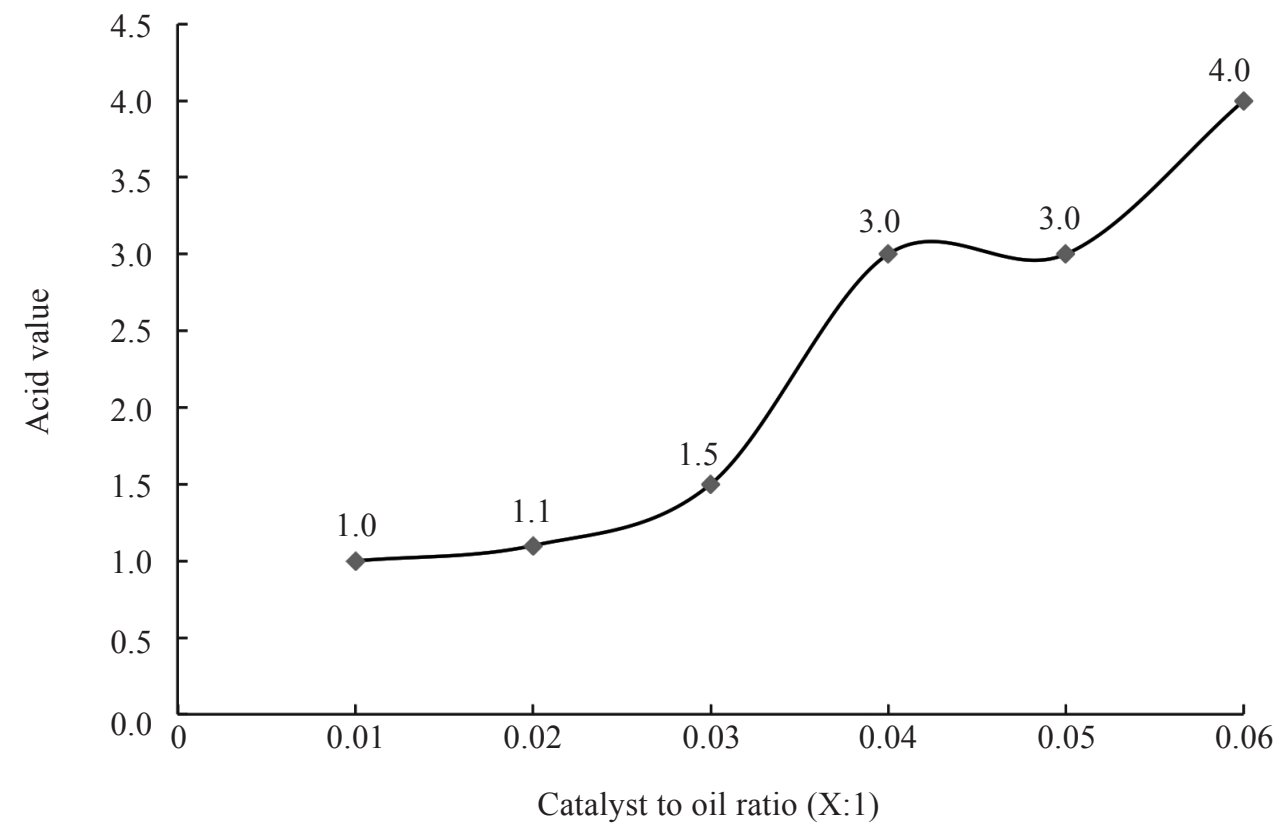

Figure 1. Acid value by different proportion of catalyst to oil ratio for Step 1 transesterification.

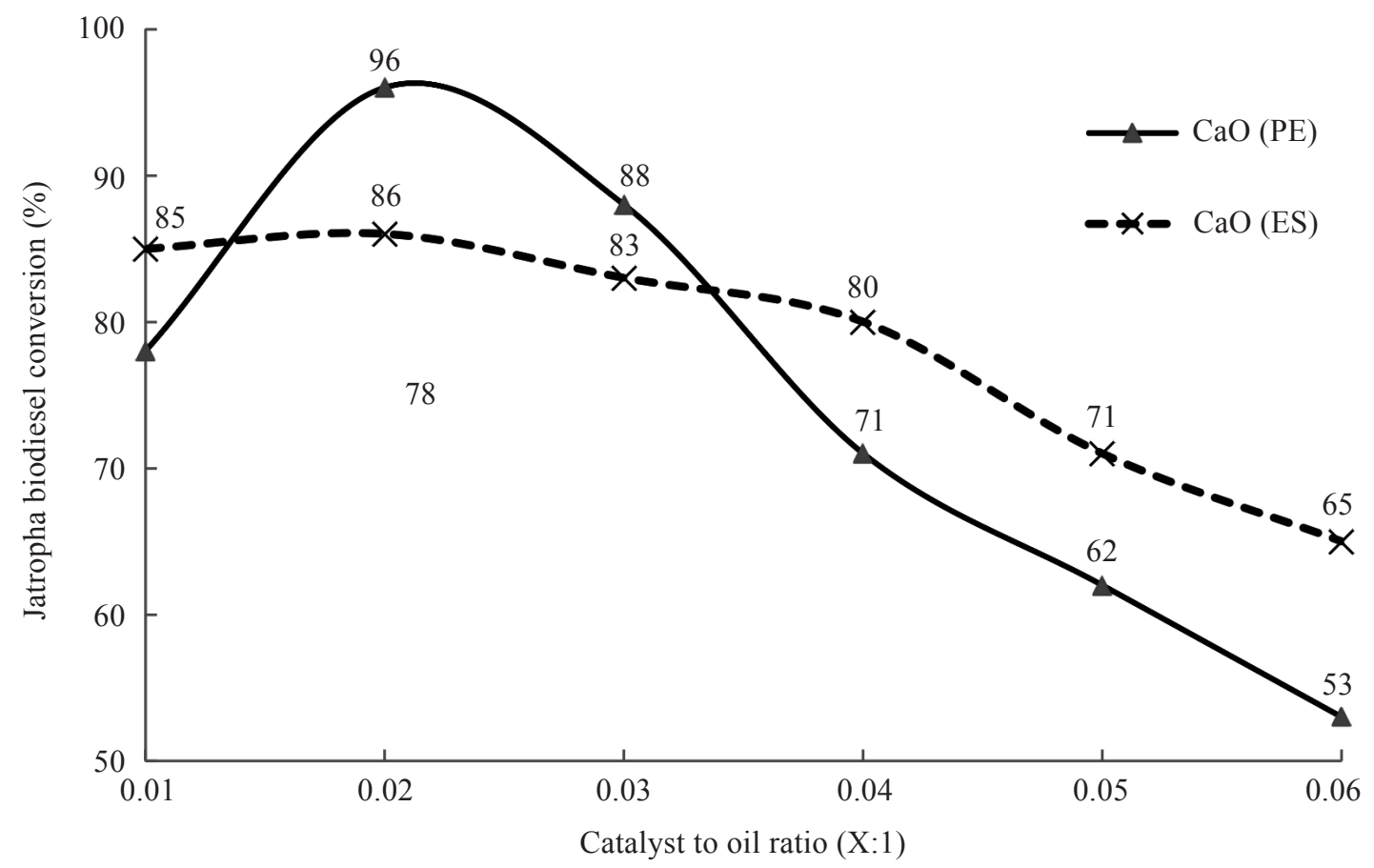

Figure 2. Biodiesel conversion by changing catalyst to oil ratio for Step 2. 


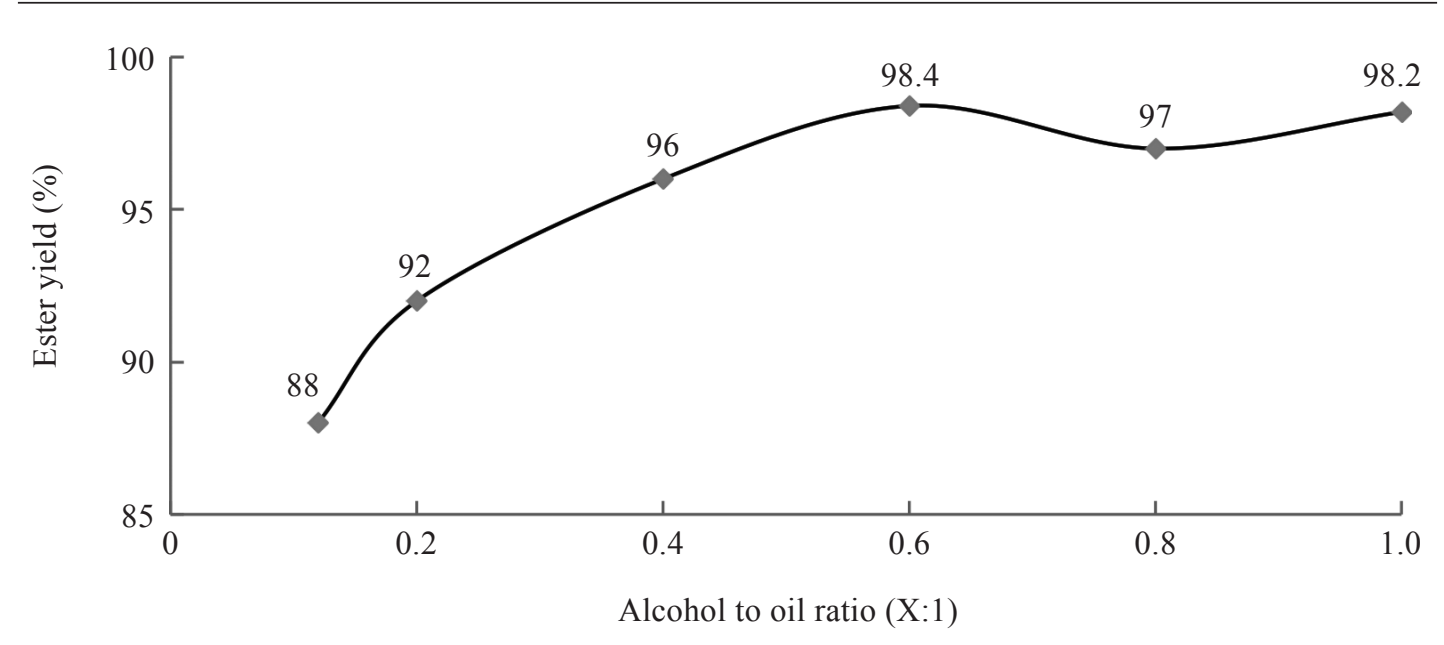

Figure 3. Ester yield by different proportion alcohol to oil ratio for Step 1 transesterification.

it was found that, $60 \%$ of methanol to oil ratio by volume showed the highest ester yield which was $98.4 \%$.

As shown in Figure 4, the amount of alcohol increased; the biodiesel yield also increased. It reached its optimum condition during alcohol to oil ratio 5:1. Further increasing of methanol led to lower conversion. This was due reverse reaction as the amount of alcohol was too high. Among the catalysts used, the optimum ratio obtained for methanol to oil was 5 to 1 and $\mathrm{CaO}$ from $P$. expansa catalyst had the highest yield at $92 \%$. Thus, $\mathrm{CaO}$ from $P$. expansa were the best catalyst among the catalysts used. From the experiments carried out it proven that the optimum ratio of methanol to oil ratio was $5: 1$, the optimum concentration of catalyst to oil ratio was $2 \%$ which gave the highest JB conversion at $96 \%$.

\section{Equipment Type}

Figure 5 shows that the Orbital Shaker (OS) converted a higher yield which averaged 92\% compared to Magnetic Stirrer (MS) cum heater, i.e. $74.33 \%$. OS showed a better and more complete mixing process for biodiesel conversion. Also, it provided more balanced mixing compared to MS which contributed to higher yield or conversion efficiency. Hence, OS was a more reliable equipment to be used in biodiesel production.

\section{Reaction Time}

Figure 6 shows that during Step 1 esterification, the optimum reaction time obtained was $1 \mathrm{~h}$. Further increase in reaction time did not contribute to a higher percentage of conversion. This was due to esterification which is a reversible process where the ester yield will be converted back to crude jatropha oil if it exceeds the optimum reaction time.

The optimum reaction time for Step 2 transesterification was $2 \mathrm{~h}$ with a conversion of $96 \%$ as shown in the Figure 7 . The rate of conversion to biodiesel increased with the reaction time until it reached $2 \mathrm{~h}$. However, further increase in reaction time exceeded the optimum condition of biodiesel yield; the yield decreased with the reversible reaction and soap formation.

\section{Analysis of Jatropha Biodiesel Properties}

Spectrum analysis. The spectrum for the biodiesel produced from two different heterogeneous catalysts derived from $P$. expansa 


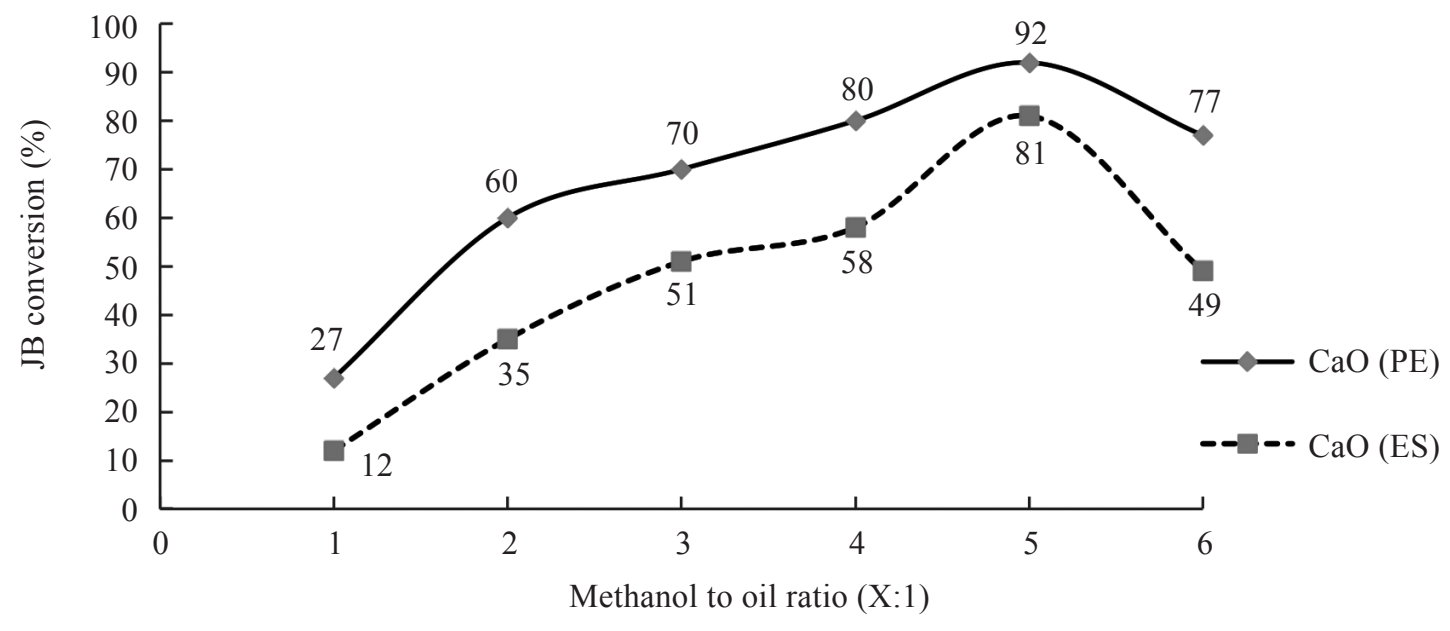

Figure 4. Biodiesel conversion by changing methanol to oil ratio for Step 2.

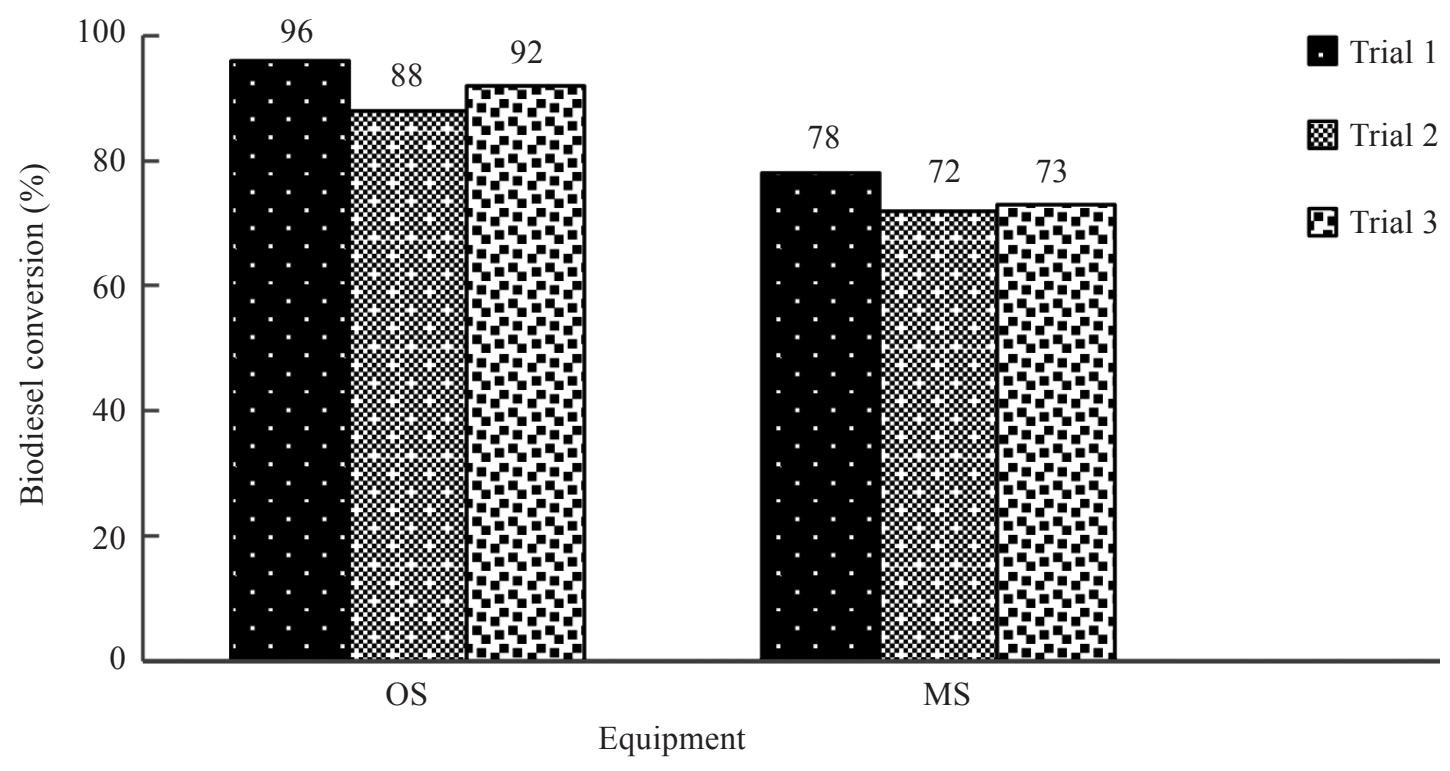

Figure 5. Biodiesel conversion by changing the types of equipment.

and eggshells was of same pattern. In Figure 8, the main difference of spectrum of biodiesel produced from mineral diesel was at $1700 \mathrm{~cm}^{-1}$ $-1750 \mathrm{~cm}^{-1}$ due to the presence of aldehyde or ester carbonyl or $\mathrm{C}=\mathrm{O}$ group. The presence of the spectrum proved that the specimen was a fatty acid methyl ester or biodiesel where the absorption bands were only present for biodiesel. Besides that, JB also showed absorption spectrums in between $1000 \mathrm{~cm}^{-1}$ $1320 \mathrm{~cm}^{-1}$ due to the presence of ester carbon oxygen group or C-O group. 


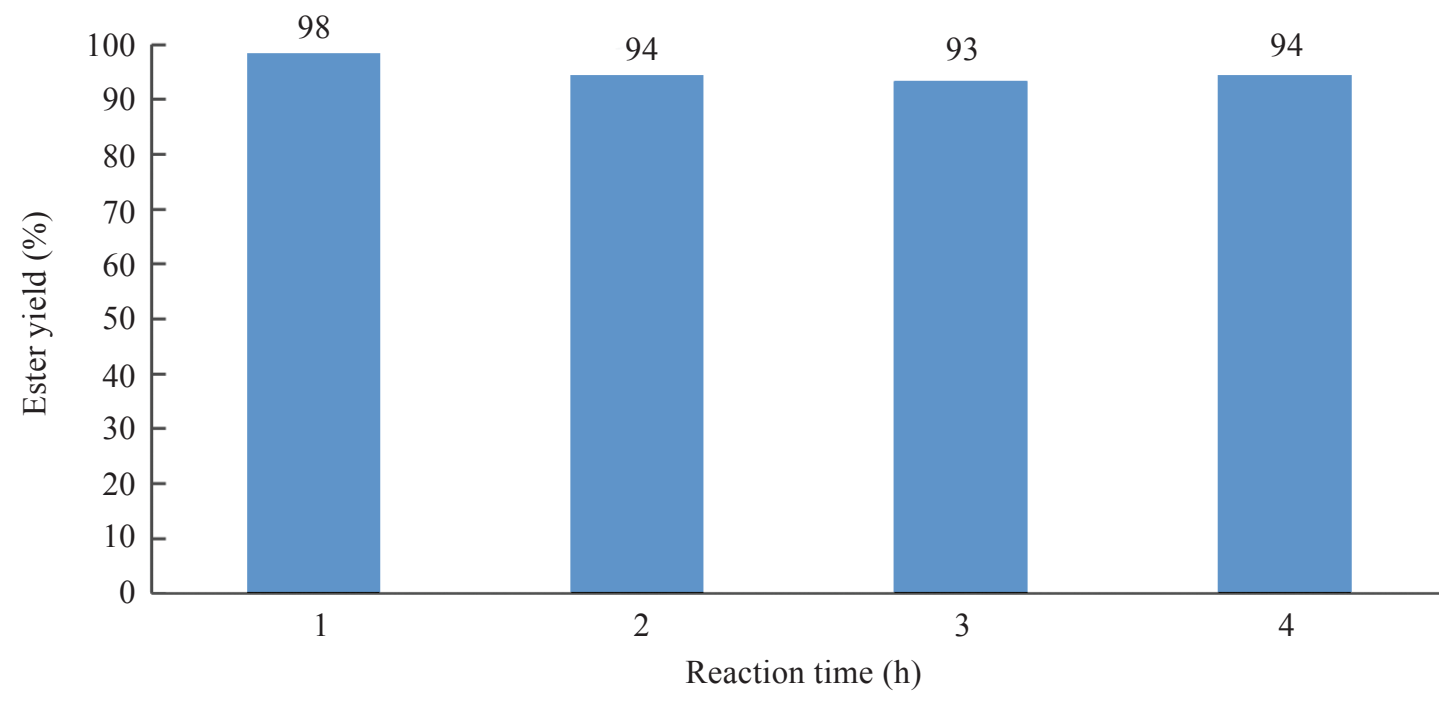

Figure 6. Reaction time to ester yield for Step 1.

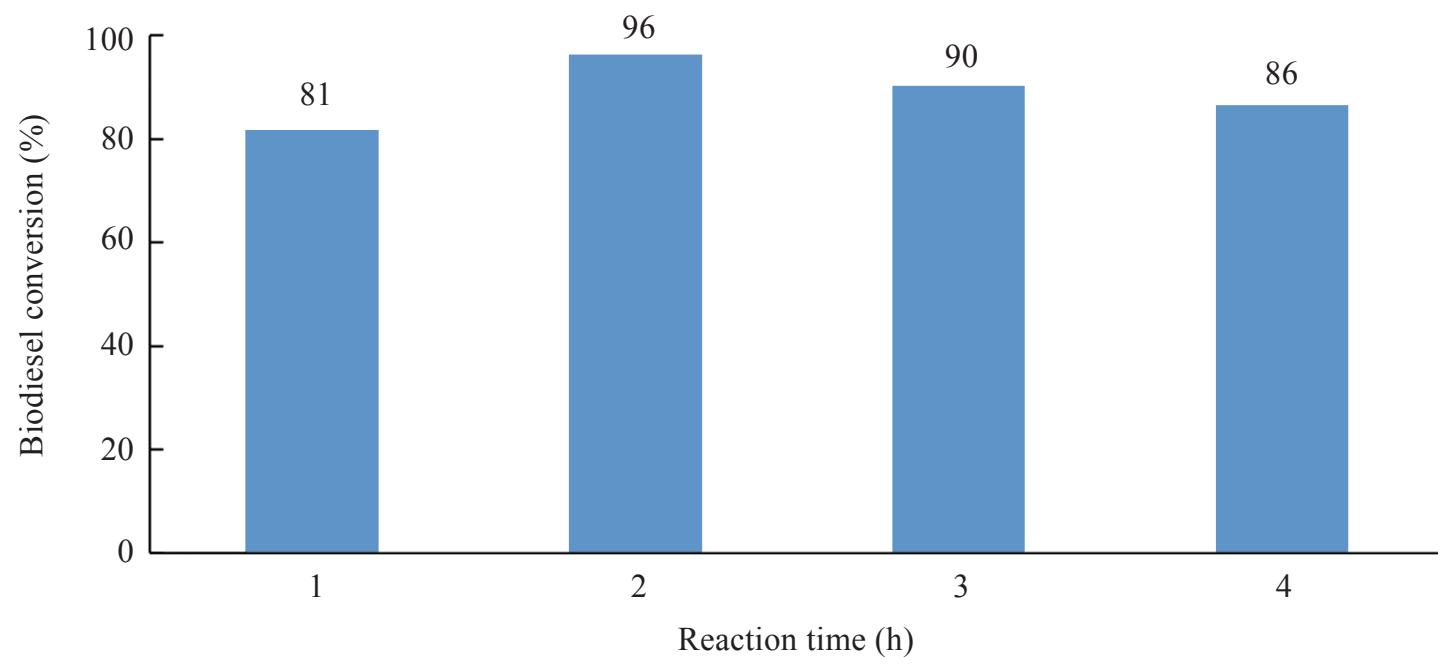

Figure 7. Biodiesel conversion to reaction time for Step 2.

\section{Calorific Value}

Caloric value is a measure of the energy produced when the fuel is burnt completely in order to determine the suitability of biodiesel as an alternative to diesel fuel. From Figure 9, diesel showed that the highest caloric value which was $43.6475 \mathrm{MJ} / \mathrm{kg}$. This was followed by CJO, $39.4381 \mathrm{MJ} / \mathrm{kg}$. JB had the lowest caloric value which was $35.4284 \mathrm{MJ} / \mathrm{kg}$. The caloric value of the JB was lower than diesel because of the oxygen content in biodiesel which was higher. Higher oxgen content improves the combustion process and decreases its oxidation potential. So, the 


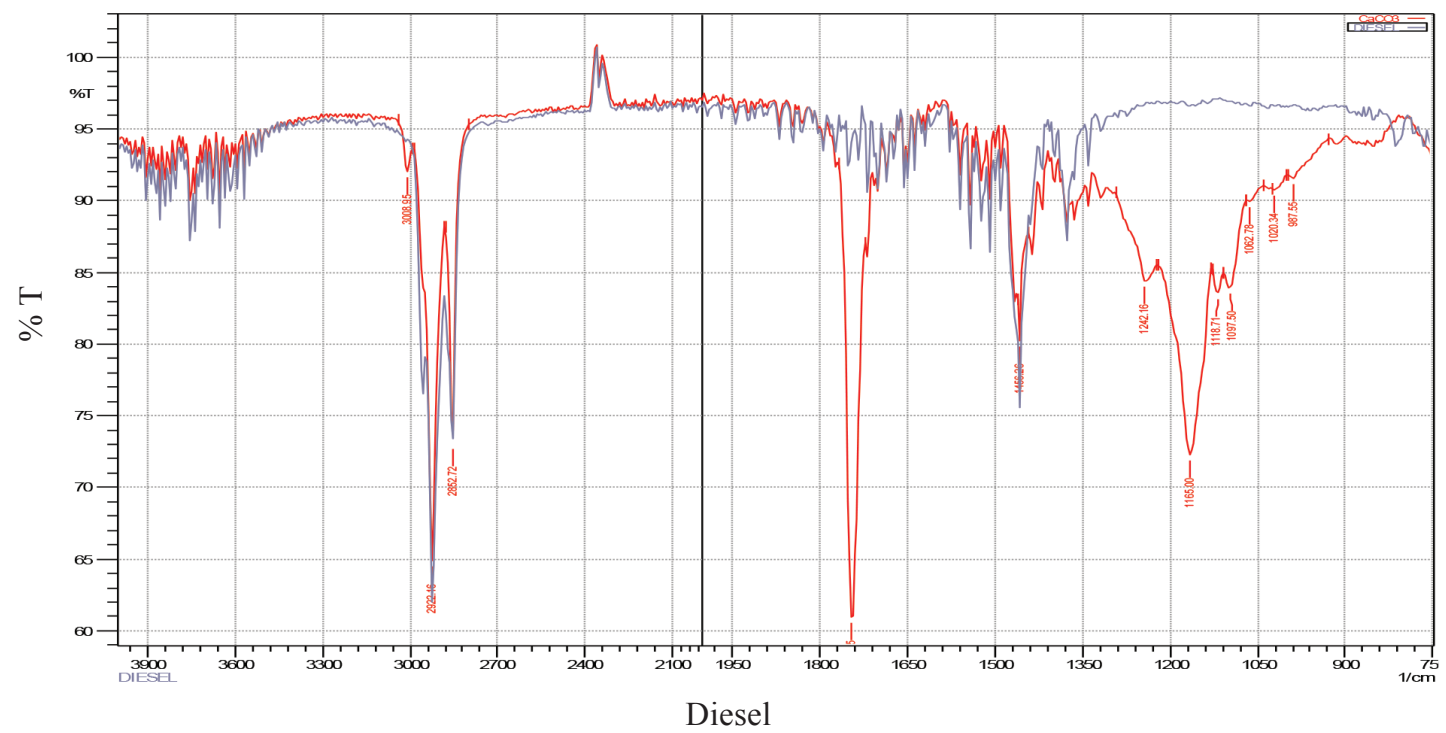

Figure 8. Infrared spectra of FAME (red) and diesel (blue).

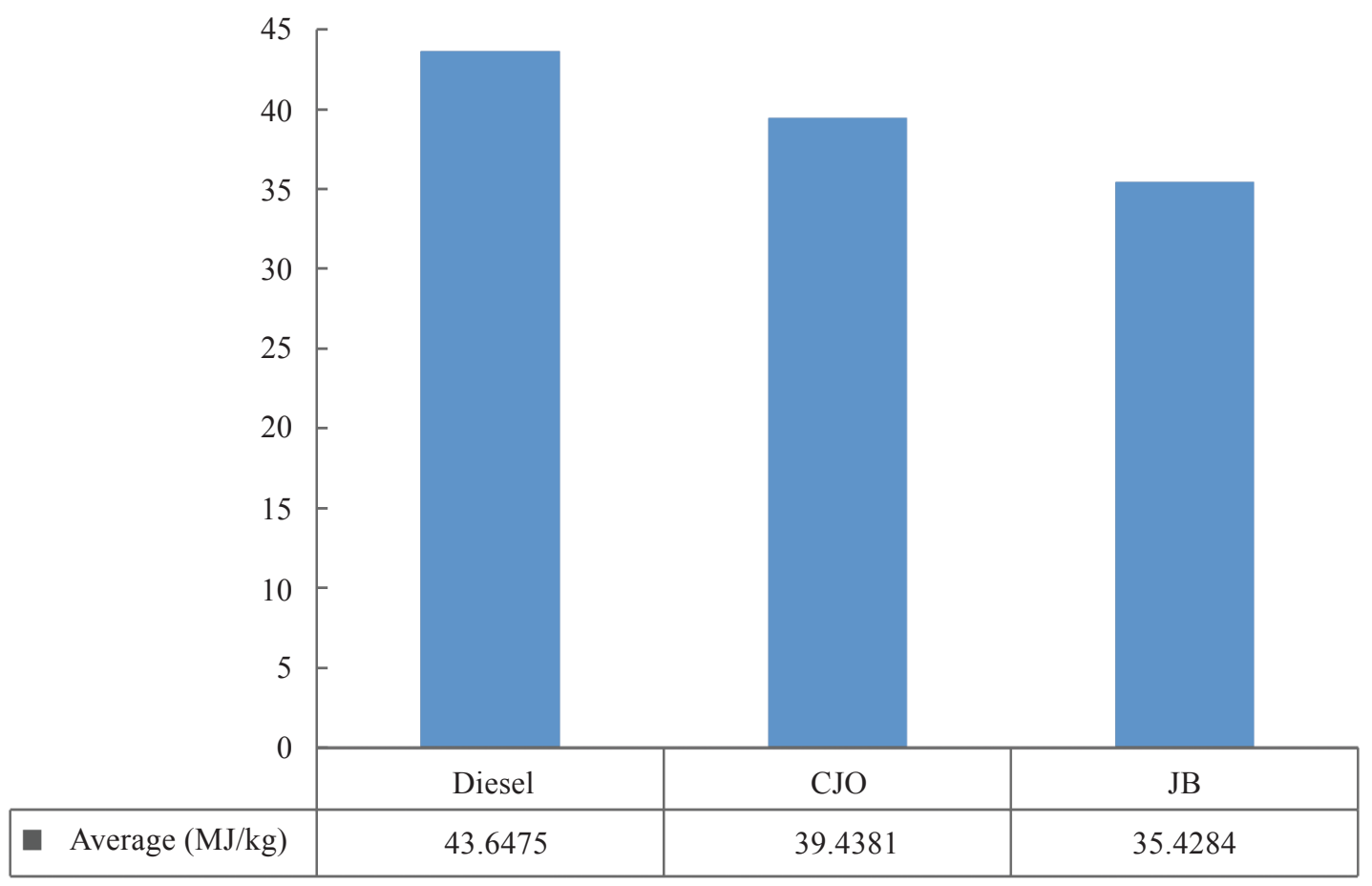

Figure 9. Analysis of calorific value. 
decrease of hydrogen and carbon content is the source of thermal energy. Thus more complete combustion leads to less emission of carbon monoxide.

\section{Density Analysis}

Density influences the efficiency of the fuel atomization for airless combustion system. It effects the break-up of fuel injected into the cylinder. The biodiesel produced from vegetable or fats are slightly denser and less compressible than the diesel fuel (Leung et al. 2010). The density measured is displayed in the Figure 10. The results shown is in the acceptable density range in accordance to the biodiesel standard DIN EN 14214 which is in between $860-900 \mathrm{~kg} / \mathrm{m}^{3}$. Thus, the biodiesel produced was comparable as the mineral diesel.

\section{Flash Point}

Flash point is the temperature at which the fuel will start to burn when it comes in contact with fire. Figure 11 showed flash point of diesel at $68, \mathrm{CJO}$ at 200 and JB at 167 . The flash point of JB was higher than diesel as JB was having volatile impurity which was very important for the engine's starting and warming. Flash point is a crucial parameter from the point of safety. This is because higher flash point demostrates safely during transport, handling and storage (Leung et al. 2010).

\section{Emissions}

In accordance to Figure 12, carbon monoxide (CO), Sulphur dioxide $\left(\mathrm{SO}_{2}\right)$, nitrogen oxide $(\mathrm{NO})$ and nitrogen dioxide $\left(\mathrm{NO}_{2}\right)$ produced in JB was lower than diesel. This was a result of a more complete combustion in JB as it was having a higher ketone number compared to petrol diesel. This is due to its long chain fatty acids with 2-3 double bonds, not aromatic and contains $10 \%-11 \%$ oxygen by weight (Koh et al. 2011). A decrease in $\mathrm{CO}$ emission was due to more oxygen content in biodiesel compared to diesel. Meanwhile, a decrease in $\mathrm{SO}_{2}, \mathrm{NO}$

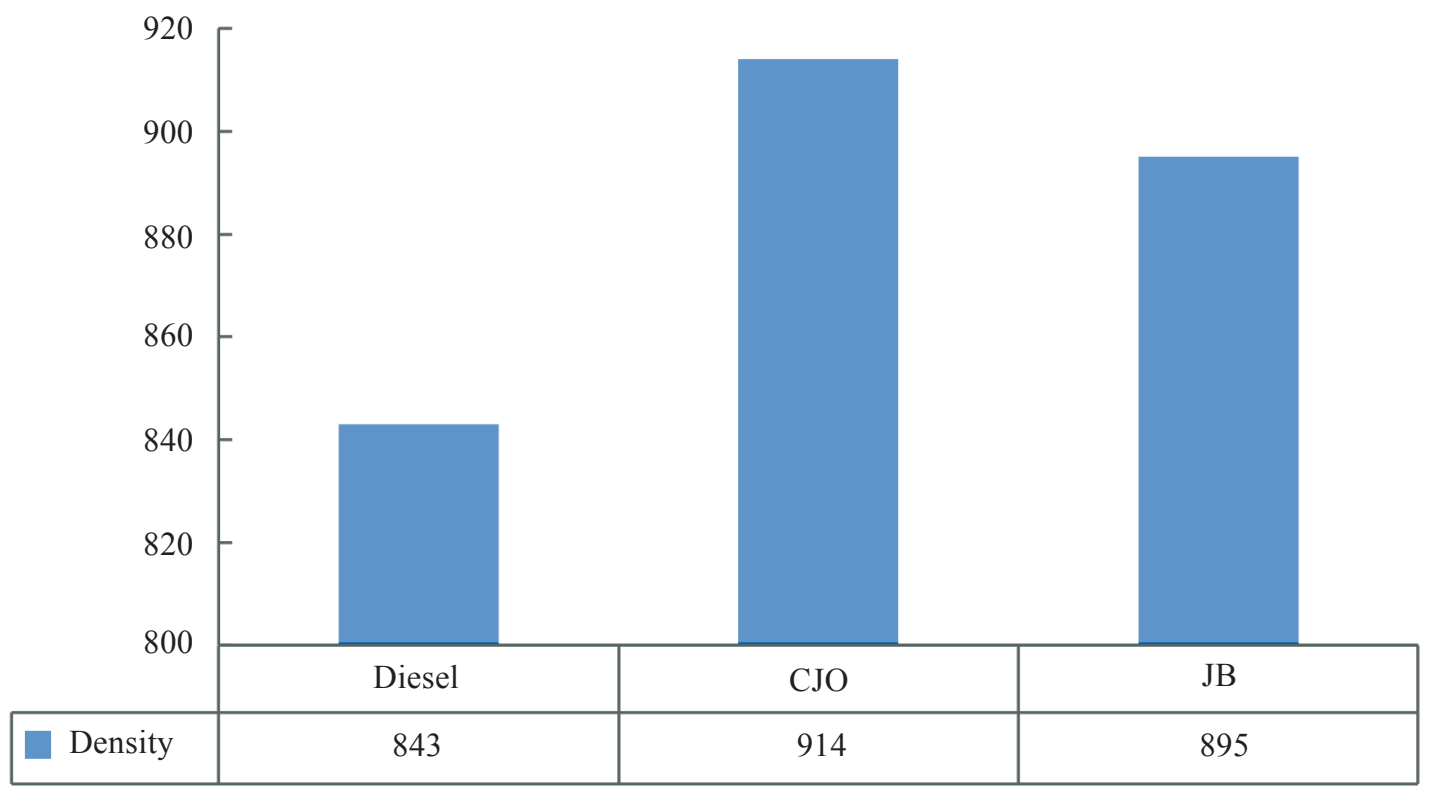

Figure 10. Density of diesel, CJO and JB. 


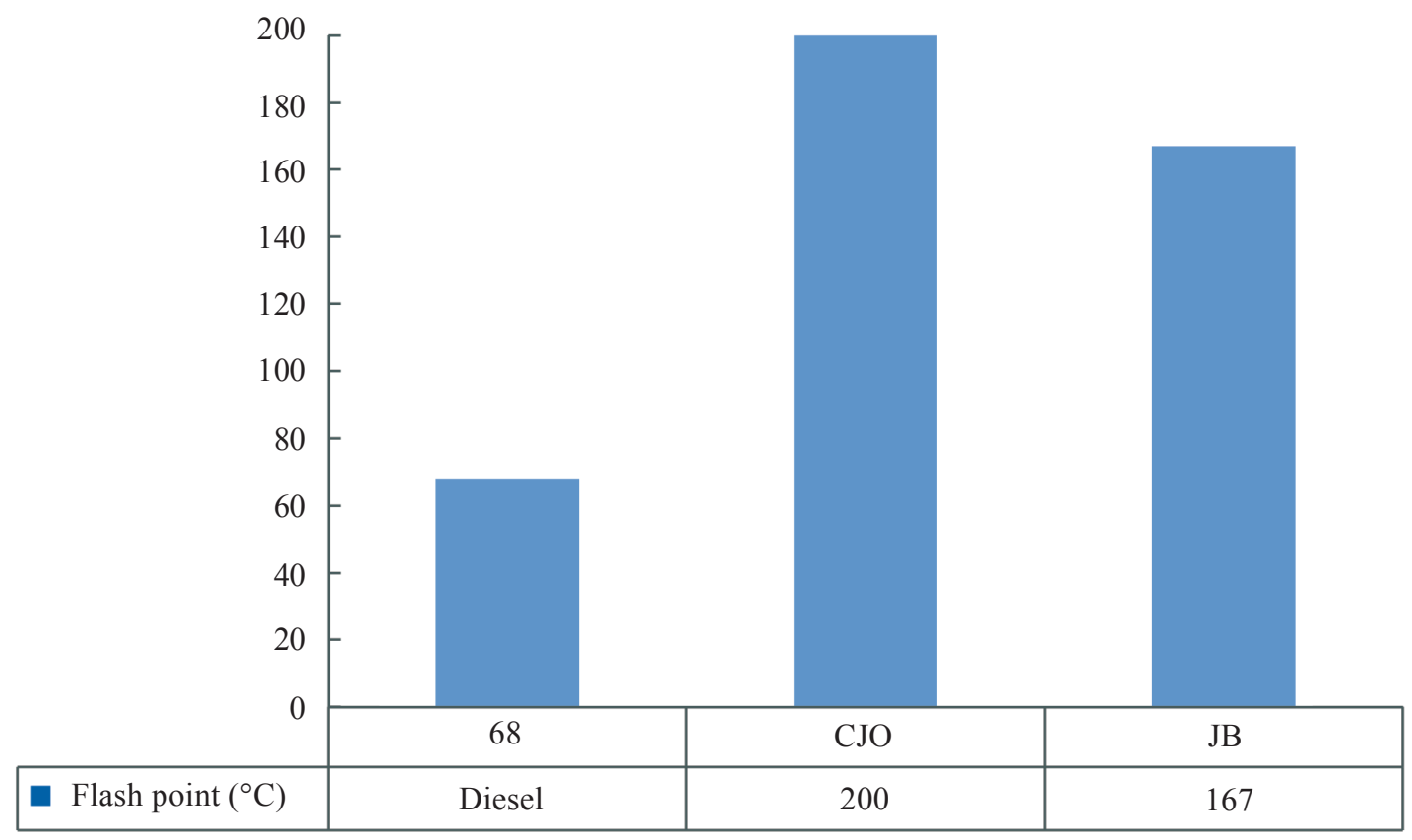

Figure 11. Flash point of diesel, CJO and JB.

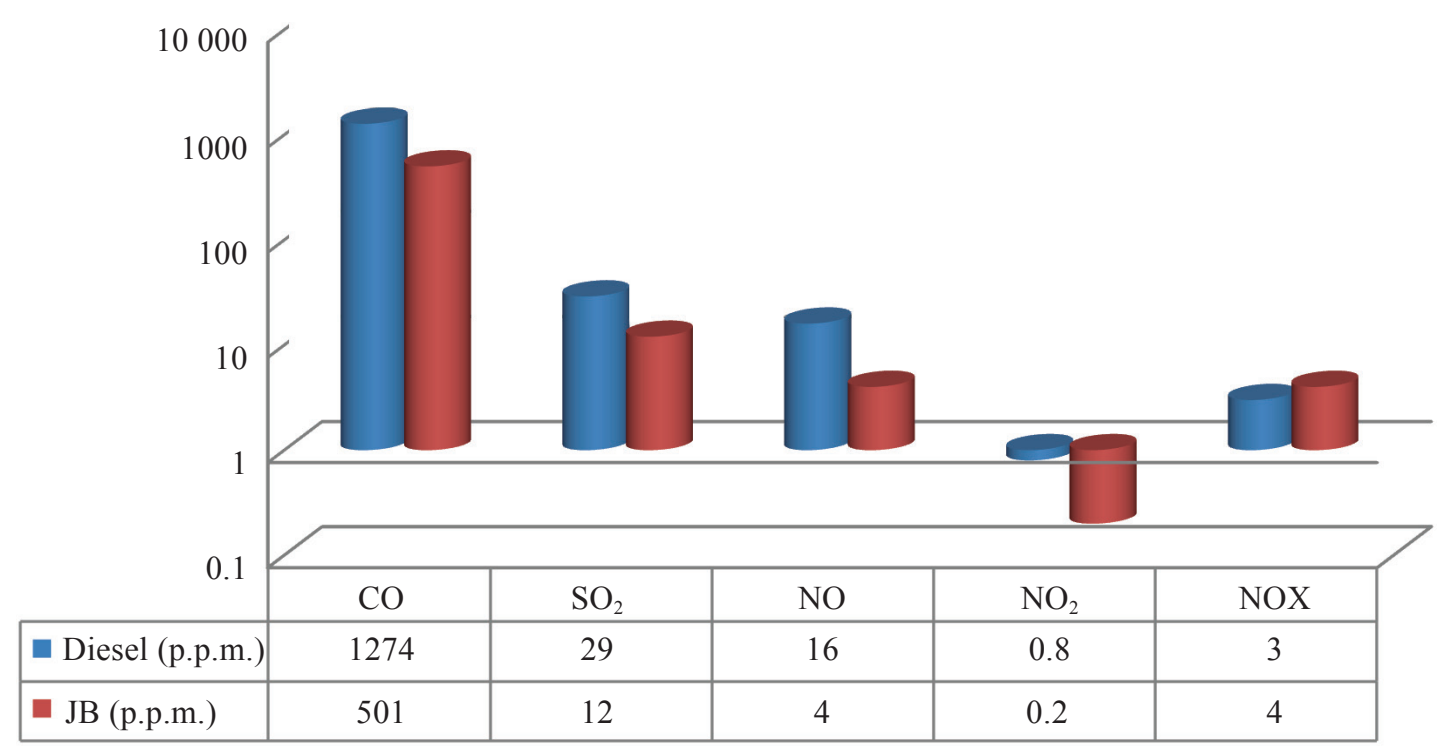

Figure 12. Emission analysis of mineral diesel and JB. 
and $\mathrm{NO}_{2}$ was due to better fuel properties of JB produced. A complete combustion led to higher combustion temperature which resulted in higher $\mathrm{NO}_{\mathrm{x}}$ formation. Other than that, high viscosity caused a bigger droplet size and shorter ignition delay might lead to the rise of the $\mathrm{NO}_{\mathrm{x}}$ emission.

\section{Diesel Engine Performance}

Diesel engine performance testing was performed to study the fuel consumption, specific fuel consumption, brake horsepower and mechanical efficiency (Edin et al. 2013). The diesel engine used was model TNMTDE-700. The experiments were carried out by preparing the JB blends by mixing mineral diesel and JB was prepared for $20 \mathrm{ml}$ for each sample. Six samples were prepared namely B0, $\mathrm{B} 10, \mathrm{~B} 20, \mathrm{~B} 30, \mathrm{~B} 40$ and B50. B0 consists of $0 \%$ of JB and $100 \%$ of mineral diesel. The load used was set to $120 \mathrm{~N}$ and the speed was set to maximum throughout the experiment. The results were presented in Table 2 and Figure 13.

Fuel consumption rate is the ratio of distance travelled over the volume of the fuel burned. It is used to measure the fuel economy as lower consumption rate represents that the fuel is more economic. B0 or pure diesel showed the lowest fuel consumption at 0.3210 $\mathrm{ml} / \mathrm{s}$. B10 to B50 were having higher fuel consumption rate due to lower calorific value of JB. Thus, JB required more fuel in order to produce the same amount of energy. Among the JB, B20 showed the lowest fuel consumption rate which was $0.3235 \mathrm{ml} / \mathrm{s}$ that was very near to B0. Thus, B20 was the optimum blending ratio.

Specific fuel consumption is a measure of fuel efficiency of any prime mover that burns fuel and produces rotational or shaft power. The specific fuel consumption rate of $\mathrm{B} 0$ or pure diesel was lower than the other JB blends as pure diesel had higher energy content. B20 showed a similar value to $\mathrm{B} 0$ which meant $\mathrm{B} 20$ was comparable to $\mathrm{B} 0$ and it showed a potential to be a substitute to diesel.

Brake horsepower is the actual or useful horsepower of an engine and its power is measured using dynamometer. Brake horse power of B0 or pure diesel was the highest while as the percentage of JB blends increased it showed a reduction in brake power. However, B20 showed an increment which was 41.5420 $\mathrm{kW}$. The decreasing is a result of lower caloric values and higher viscosities as both factors

Table 2. Diesel engine performance study calculation for B0 to B50.

\begin{tabular}{l|cccccc}
\hline \multicolumn{1}{c|}{ Engine performance } & \multicolumn{7}{c}{ JB Blends } \\
& B0 & B10 & B20 & B30 & B40 & B50 \\
\hline Torque (N.m) & 36 & 36 & 36 & 36 & 36 & 36 \\
Fuel consumption rate $(\mathrm{ml} / \mathrm{s})$ & 0.3210 & 0.3309 & 0.3235 & 0.3381 & 0.3389 & 0.3424 \\
Engine power output $(\mathrm{kW})$ & 1.3500 & 1.3410 & 1.3500 & 1.3261 & 1.3112 & 1.3024 \\
Specific fuel consumption $(\mathrm{mL} / \mathrm{kW})$ & 14.8148 & 14.9142 & 14.8148 & 15.0818 & 15.2532 & 15.3563 \\
Brake horsepower & 41.5579 & 41.5342 & 41.5420 & 41.5027 & 41.4946 & 41.4709 \\
Indicated horsepower $(\mathrm{kW})$ & 57.8 & 57.8 & 57.8 & 57.8 & 57.8 & 57.8 \\
Mechanical efficiency, $\mathrm{n}(\%)$ & 71.8994 & 71.8584 & 71.8720 & 71.8039 & 71.7900 & 71.7490 \\
\hline
\end{tabular}




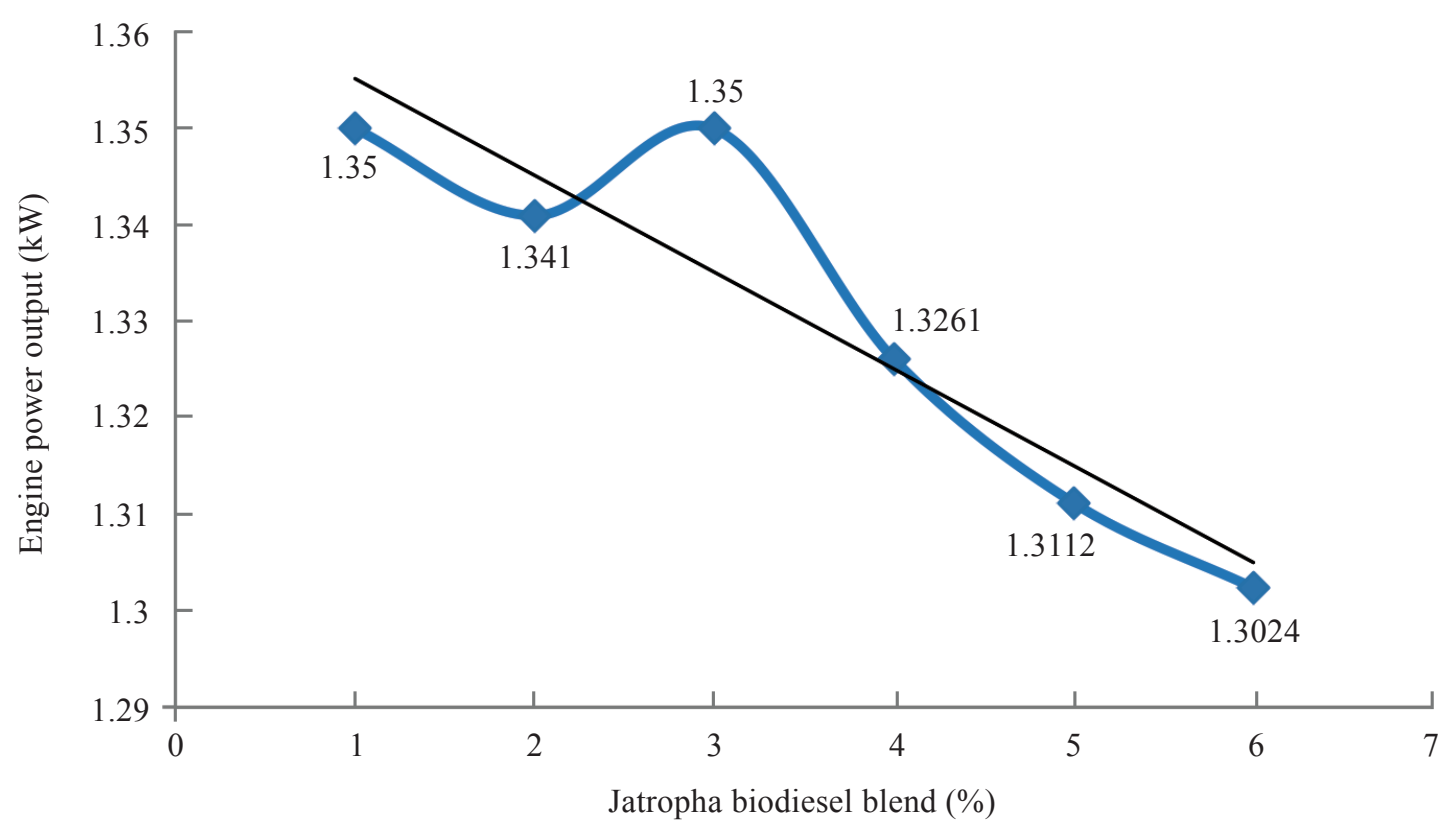

Figure 13. Mechanical efficiency versus jatropha biodiesel blends.

have an effect on combustion. An uneven combustion characteristic of biodiesel also contributes to decline in the percentage of break power.

Mechanical efficiency refers to the measurement of the effectiveness of the diesel engine in transforming the energy and power that is input to the diesel engine into output mechanical work or in other words to measure the engine performance. B0 had the highest energy efficiency which was $71.8994 \%$ compare to the other JB blends. As percentage of JB blends increased, the mechanical efficiency decreased except for B20 which showed an increment. The results showed that B20 was the optimum blend and performed as comparable to diesel.

\section{CONCLUSIONS}

In this study, a heterogeneous catalyst from seashells and eggshells was synthesized and used for biodiesel production. During
Step 1, acid pretreatment process the identified optimum catalyst to oil ratio was $0.01: 1$ and the optimum methanol to oil ratio was $0.6: 1$. On the other hand, for Step 2, base-catalyzed process the optimum to oil ratio was $0.02: 1$ and the optimum methanol to oil ratio was 5:1. Among the catalysts used, $\mathrm{CaO}$ from $P$. expansa performed the best. The optimum reaction time for Step 1 was $1 \mathrm{~h}$ while for Step 2 it was $2 \mathrm{~h}$. For equipment, orbital shaker showed a higher conversion rate compared to magnetic stirrer cum heater due to its better mixing rate. The highest rate of conversion of the JB yield was $96 \%$.

For FT-IR analysis, the main differences in the spectrum of JB produced from mineral diesel were strong infrared absorption at $1700 \mathrm{~cm}^{-1}-1750 \mathrm{~cm}^{-1}$ due to the presence of aldehyde, $\mathrm{C}=\mathrm{O}$ group. The presence of $\mathrm{C}=\mathrm{O}$ group confirmed the specimen to be biodiesel or fatty acid methyl esters. Other functional groups such as $\mathrm{C}-\mathrm{O}, \mathrm{C}-\mathrm{H}$ were also present. For calorific value analysis, JB had the lowest 
calorific value among CJO and diesel. This was due to higher oxygen content and led to more complete combustion in JB. So, the hydrogen and carbon content decreased which was the source of the thermal energy. For density analysis, the JB produced had a density of 895 $\mathrm{kg} / \mathrm{m}^{3}$ which was higher than the mineral diesel and lower than CJO. The biodiesel produced was comparable to mineral diesel as it fell in the acceptance density range of biodiesel standard DIN EN 14214 which is $860 \mathrm{~kg} / \mathrm{m}^{3}-900 \mathrm{~kg} /$ $\mathrm{m}^{3}$. For flash point analysis, JB had a flash point of 167. It is safer and cheaper for transport, handling as well as for storage compared to mineral diesel which had a flash point of 68 . From the diesel engine performance testing conducted, it was found that JB of B20 was the optimum ratio as it had the lowest fuel consumption rate, highest brake horsepower and highest mechanical efficiency among the JB blends. JB showed a similar characteristics of mineral diesel. Therefore, it had the potential to act as a substitute for diesel.

\section{ACKNOWLEDGEMENTS}

This study was supported by the Department of Mechanical and Manufacturing Engineering, Faculty of Engineering, University Malaysia Sarawak, Malaysia.

Date of submission: March 2015

Date of acceptance: August 2015

\section{REFERENCES}

Azhari, M, Yunus, FR, Mohd. Ghazi, TI \& Yaw TCS 2008, 'Reduction of free fatty acids in crude Jatropha Curcas oil via an esterification process', International Journal of Engineering and Technology, vol. 5, no. 2, pp. 92-98.

Azimah, AR, Mohd Hanafi, I, Abu, HMK, Wong, SK \& Arshad, A 2012, 'Analysis of condition index in Polymesoda expansa (Moussson 1849)' Pak. J. Biol. Sci., vol. 15, no. 13, pp. 629-634.

Bachok, Z, Mfilinge, PL \& Tsuchiya, M 2003, 'The diet of the mud clam Geloina coaxans (Mollusca,
Bivalvia) as indicated by fatty acid markers in a subtropical mangrove forest of Okinawa, Japan,' Journal of Experimental Marine Biology and Ecology, vol. 292, no. 2, pp. 187-197.

Bobade, SN, Kumbhar, RR \& Khyade VB 2013, 'Preparation of methyl ester (biodiesel) from Jatropha curcas Linn oil', Research Journal of Agriculture and Forestry Sciences, vol. 1, no. 2, pp. 12-19.

Bojan, SG \& Durairaj SK 2012, 'Producing biodiesel from high free fatty acid Jatropha curcas oil by a two step method - an Indian case study', Journal of Sustainable Energy \& Environment, vol. 3, pp. 63-66.

Buasri, A, Chaiyut, N, Loryuenyong, V, Wongweang, C \& Khamsrisuk, S 2013, 'Application of eggshell wastes as a heterogeneous catalyst for biodiesel production', Sustainable Energy, vol. 1, no. 2, pp. 7-13.

Chung, KH, Chang, DR \& Park, BG 2008, 'Removal of free fatty acid in waste frying oil by esterification with methanol on zeolite catalysts', Bioresource Technology, vol. 99, pp. 7438-7443.

Cluzel, C 2013, The role of biofuels beyond 2020, BP, Element Energy Limited, Cambridge.

Demirbas A, 2009, 'Progress and recent trends in biodiesel fuels', Energy Conversion and Management, vol. 50, no. 1, pp. 14-34.

Deng X, Fang Z \& Liu YH 2010, 'Ultrasonic transesterification of Jatropha curcas L. oil to biodiesel by a two-step process', Energy Conversion Management, vol. 51, pp. 2802-2807.

Gubitz, GM, Mittelbach, M, Trebi, M \& Trabi, M 1999, 'Exploitation of tropical oil seed plant Jatropha Curcas L.', Bioresource Technology, vol. 67, pp. 73-82.

Gui, MM, Lee, KT \& Bhatia, S. 2008, 'Feasibility of edible oil vs. non-edible oil vs. waste edible oil as biodiesel feedstock', Energy, vol. 33, pp. 1646-1653.

Srithar, K, Balasubramanian, KA, Pavendan, V \& Kumar, BA 2014, 'Experimental investigations on mixing of two biodiesels blended with diesel as alternative fuel for diesel engines', Journal of King Saud University - Engineering Sciences, $<$ http://dx.doi.org/10.1016/j.jksues.2014.04. $008>$.

Koh, MY \& Chazi, TI 2011, 'A review of biodiesel production from Jatropha Curcas L. oil', 
Renewable and Sustainable Energy Reviews, vol. 15 , no. 5, pp. 2240-2251.

Leung, YCD, Wu, X \& Leung, MKH 2010, 'A review on biodiesel production using catalyzed transesterification', Applied Energy, vol. 87, no. 4, pp. 1083-1095.

Lippke, B, Gustafson, R, Venditti, R, Volk, T, Oneil, E, Johnson, L, Puettmann, M \& Steele, P 2011, 'Sustainable biofuel contributions to carbon mitigation and energy independence', Forests, vol. 2, pp. 861-874.

Marchetti, JM, Miguel, VU \& Errazu, AF 2007, 'Possible methods for biodiesel production,' Renewable and Sustainable Energy Reviews, vol. 11 , no. 6, pp. 1300-1311.

Meher, LC, Churamani, CP, Arif, M, Ahmed, Z \& Nail, SN 2013, 'Jatropha curcas as a renewable source for bio-fuel-A review', Renewable and Sustainable Energy Reviews, vol. 26, pp. 397-407.

Mofijur, M, Masjuki, HH, Kalam, MA, Hazrat, MA, Liaquat, AM, Shahabuddin, M \& Varman, M 2012, 'Prospects of biodiesel from Jatropha in Malaysia', Renewable and Sustainable Energy Reviews, vol. 16, pp. 5007-5020.

Mustakimah, M, Suzana, Y \& Maitra, S 2012, 'Decomposition study of calcium carbonate in cockle shell', Journal of Engineering Science and Technology, vol. 7, no. 1, pp.1-10.
Nahar, K \& Ozores-Hampton, M 2011, 'Jatropha: an alternative substitute to fossil fuel', Horticultural Sciences Departments Florida: Institute of Food and Agriculture Science, University of Florida, pp. 1-9.

Qien, JF, Shi, HX \& Zhi, T 2010, 'Preparation of biodiesel from Jatropha curcas L. oil produced two-phase solvent extraction', Biosource Technology, vol. 101, no. 18, pp. 7025-7031.

Ismail, S, Abu, SA, Rezaur, R \& Sinin, H 2014, 'Biodiesel production from castor oil and its application in diesel engine', ASEAN J. Sci. Technol. Dev., vol. 31, no. 2, pp. 91-101.

Said, N, Fatimah, A, Misebah, Siti FH, Nur, SG, Rosli, MY \& Gimbun, J 2014, 'Activated Paphia undulata shells waste (APSW): a cost-effective catalyst for biodiesel synthesis from rubber and Jatropha curcas seeds oil (RSOME \& JSOME)" International Journal of Chemical Engineering and Applications', vol. 5, no. 6, pp. 483-488.

Edin, T, Ahmed, AS, Rahman, R \& Hamdan, S 2013, 'Biodiesel production from jatropha oil as an alternative fuel for diesel engine', Journal of Energy \& Environment, pp. 18-24.

Yang, CY, Deng, X, Fang, Z \& Peng, DP 2010, 'Selection of high oil yield seed sources of Jatropha curcas L. for biodiesel production', Biofuels, vol. 1, pp. 705-717. 